\title{
ASSESSMENT OF BAD LOANS IN TURKEY: WHAT ROLE DO FINANCIAL CONDITIONS HAVE?
}

\section{TÜRKIYYE'DE SORUNLU KREDİLERİN DEĞERLENDİRILMESİNDE FINANSAL KOŞULLARIN ROLÜ}

\author{
Vuslat US*
}

\begin{abstract}
This paper analyzes non-performing loans in the Turkish banking sector with a special focus on the role of financial conditions after the global crisis. In doing so, the empirical framework shows that the determinants of non-performing loans have changed after the crisis. In particular, non-performing loans are mostly shaped by bank-specific factors before the crisis, whereas these variables have a reduced effect after the global crisis. This finding is attributed to global developments in this period, which certainly had effects on both global and domestic financial conditions. The inclusion of financial conditions index as an additional regressor in the post-crisis episode also confirms this finding by yielding a statistically significant coefficient while the sign of the coefficient implies that tighter financial conditions cause higher non-performing loans. This supports our view that financial conditions take account for the dynamics of bad loans after the crisis. In the upcoming period, the course of global policy normalization may affect and even tighten financial conditions, thereby causing non-performing loans to gain momentum. All these analysis results signal challenges and prospects regarding the maintenance of financial stability and the conduct of monetary policy.
\end{abstract}

Keywords: Non-performing loans, Turkish banking sector, Global crisis, Financial conditions index, Financial stability.

JEL Codes: C23, E44, E52, G10, G21.

\section{Öz}

Bu çalışmada, Türk bankacılık sektöründeki takipteki alacaklar küresel kriz sonrasında değişen finansal koşulların rolü mercek altına alınarak incelenmektedir. Bu doğrultuda sunulan ampirik çerçevede takipteki alacakların belirleyicilerinin küresel kriz sonrasında değiştiği gösterilmektedir. Bir diğer deyişle, küresel kriz öncesinde daha çok bankaya özgü etkenlerle belirlenen takipteki alacaklar, kriz sonrasında bu değişkenlerden daha az etkilenmektedir. Bu bulgu, kriz sonrası dönemde gerek küresel gerekse ülke düzeyindeki finansal koşulların büyük ölçüde küresel gelişmelere bağlı olarak değişmesiyle açıklanmaktadır. Küresel kriz

* Central Bank of the Republic of Turkey, Research and Monetary Policy Department. Phone: +90 312.507.5423, e-mail: vuslat.us@tcmb.gov.tr. All views expressed in this paper are solely of the author and do not represent the views of the affiliated institution. Usual caveats apply regarding errors and omissions. 
sonrası döneme ilişkin yapılan analize ek açılayıcı değişken olarak dâhil edilen finansal koşullar endeksinin istatiksel olarak anlamlı sonuç vermesi ise bu bulguyu teyit etmekte ve sıkı finansal koşulların takipteki kredilerde artış ima ettiğini ortaya koymaktadır. Bu durum, kriz sonrası dönemde sorunlu kredilerin dinamiklerinin finansal koşullara bağlı olarak değiştiği görüşümüzü desteklemektedir. Önümüzdeki dönemde küresel ölçekte gerçekleşmesi beklenen para politikasına ilişkin normalleşme sürecinin finansal koşulları etkilemesi ve hatta sıkılaştırması beklenmektedir. Bunun sonucunda ise takipteki alacakların ivme kazanması olası gözükmektedir. Elde edilen tüm analiz sonuçları, finansal istikrarın sürdürülmesi ve para politikasının uygulanması açısından zorluk ve firsatlara işaret etmektedir.

Anahtar Kelimeler: Türk bankacılık sektörü, Takipteki alacaklar, Küresel kriz, Finansal koşullar endeksi, Finansal istikrar.

JEL Kodları: C23, E44, E52, G10, G21.

\section{Introduction}

The global crisis and the subsequent recessions had a dramatic impact on financial markets. The effects of the crisis were mostly condensed to mounting risk perception, heightened instability and escalated credit risk. In turn, these crisis-induced developments had repercussions on non-performing loans (NPLs), forcing most countries to grapple with large stocks of impaired loans. Obviously, the high and rising level of debt overhang in many countries sparked by the global crisis posed significant challenges to financial stability. Given that NPLs can be used as leading indicators ${ }^{1}$ to identify key financial vulnerabilities, these brought renewed attention to understanding the determinants of bad loans.

Meanwhile, Turkish banks were also exposed to rising risks associated with higher NPLs in the post-crisis period. In fact, CBRT (2010, p. 23), Selçuk (2010, p. 21) and Afşar (2011, p. 161) show that NPLs increased sharply after the crisis. Moreover, Us (2016a, p. 1) report that the dynamics of NPLs have changed after the crisis by asserting that NPLs are determined mostly by bank-specific factors before the crisis, while macroeconomic and policy-related factors are more influential on NPLs after the crisis. Furthermore, Us (2016b, p. 186) conducts a similar analysis and states that the ongoing normalization of global monetary policies is likely to tighten financial conditions, which may prompt potential challenges and prospects for the NPL dynamics in the Turkish economy. By extending the dataset, the study concludes that NPLs are shaped mostly by macroeconomic factors amid the changing global financial conditions, which pose risks to domestic financial stability.

In view of the previous findings that NPLs increased sharply after the crisis besides the empirical evidence that the determinants of NPLs have changed during the same period, this study tries to explain the dynamics of NPLs before and after the global crisis by bank-specific factors as

1 Reinhart and Rogoff (2011, p. 1680) point out that the rise in NPLs can be used to mark the onset of a banking crisis. 
well as macroeconomic and policy-related variables. ${ }^{2}$ In addition, the study also addresses the issue of persistence ${ }^{3}$ by including the lagged dependent variable term among regressors.

However, this paper tries to contribute to the existing literature by also considering the role of financial conditions on NPLs. This is done so by adding financial conditions index (FCI) to the set of NPL determinants in the post-crisis episode. FCI is an index capturing the effects of domestic and global factors in assessing financial conditions. It is measured as a weighted sum of several variables including the exchange rate, risk premium, capital flows, benchmark interest rate, stock return, credit rate, credit standards and the slope of the yield curve. ${ }^{4,5,6,7}$

The inclusion of FCI yields a highly significant coefficient. This shows that the role of financial conditions should be taken into account in evaluating ex-post credit risk, which provides an important feedback for financial stability. Given that central banks in emerging economies, including the Central Bank of the Republic of Turkey (CBRT), were compelled by the global crisis to

2 Salas and Saurina (2002), Jiménez and Saurina (2006), Louzis et al. (2012), Rinaldi and Sanchis-Arellano (2006), Berge and Boye (2007), Berger and DeYoung (1997), Podpiera and Weill (2008) and Sinkey and Greenawalt (1991) are important works along this line.

3 Klein (2013, p. 10), Louzis et al. (2012, p. 1021), Jiménez and Saurina (2006, p. 71) and Rinaldi and Sanchis-Arellano (2006, p. 19) are previous studies that assume persistence in NPLs, which implies that lagged NPL terms have significant impact on current NPLs due to delay in write-off.

4 Financial conditions can be defined as the current state of financial variables that influence economic behavior and the future state of the economy (Hatzius et al., 2010, p. 1). In theory, such financial variables may include anything that characterizes the supply or demand of financial instruments relevant for economic activity. FCI summarizes the information about the future state of the economy contained in these current financial variables. In theory, there is a long list of potential financial measures to include in an FCI. This ranges from equity prices, the shape of the yield curve and measures of credit risk, which have commonly been used as financial indicators of future economic activity, to other financial measures, which affect household wealth - including those of equities and houses, or consumer interest rates that affect the trade-off between the present consumption and the future consumption (Hatzius et al., 2010, p. 5).

5 Early research on financial conditions centered on the slope of the yield curve, which was perceived as a reliable indicator for economic activity (Estrella and Hardouvelis, 1991, p. 555; Harvey, 1988, p. 303). Interest rate spread was another common variable selected as a leading indicator for GDP (Laurent, 1989, p. 22). Credit risk has also been used as a leading indicator of output (Gilchrist et al., 2009, p. 471). Moreover, stock market performance has been found to be a useful indicator as well (Estrella and Mishkin, 1998, p. 45).

6 FCI for Turkey was developed originally by Kara et al. (2012, p. 2) and improved further by Kara et al. (2015, p. 41) as a measure to assess the effects of domestic and global factors in financial conditions and to provide an intuitive account of the post-crisis monetary and financial stance. Accordingly, the index shows whether the overall set of policies are restrictive or accommodative. FCI is estimated as a weighted sum of some selected relevant variables and the weight of each variable, which is estimated within a Vector Autoregressive (VAR) framework, reflects the relative importance of that variable in explaining the future output growth (Kara et al., 2015, p. 41).

7 Despite the presence of a variety of methods, the two popular techniques developed to construct FCI are the weighted sum approach and the principal components approach. In the weighted sum approach, the weights on each financial variable are generally assigned based on estimates of the relative impacts of changes in the variables on real GDP. These estimates or weights can be measured by various ways, including simulations with large-scale macroeconomic models, VAR models or reduced-form demand equations. The second popular approach is the principal components methodology, which extracts a common factor from a group of several financial variables. This common factor captures the greatest common variation in the variables and is either used as the FCI or is added to the central bank policy rate to make up the FCI using a combination of the weighted sum approach and the principal components approach (Hatzius et al., 2010, p. 7). 
observe financial stability, this analysis is also useful for the conduct of monetary policy, which also addresses macroprudential concerns. ${ }^{8,9}$

Hence, this paper seeks to take a snapshot of the NPLs in the Turkish banking sector with the ultimate goal to assess challenges and prospects under the current outlook. The paper is organized as follows: The next section presents data and the econometric methodology. The following section reports the estimation results. Finally, the last section concludes. All tables are presented in the Appendix.

\section{Data and the Econometric Methodology}

\section{I. Data}

The paper utilizes quarterly data during 2002Q4 and 2015Q4 for 21 deposit banks in the Turkish banking system. Tables A1-A2 present the description of the variables and their descriptive statistics. Bank-specific data are obtained from the Banks Association of Turkey, while other data are compiled from the electronic data dissemination system of the CBRT. The dependent variable is the NPL ratio, while bank-specific variables capture capital adequacy, profitability, lending, inefficiency and bank size. Macroeconomic and policy-related explanatory variables include the real GDP growth, inflation, exchange rate, policy rate and FCI.

\subsection{Econometric Methodology}

The dynamics of NPLs can be analyzed by the following general equation:

$$
N P L_{i, t}=\alpha+\gamma N P L_{i, t-1}+\beta_{1} \text { Bank }_{i, t-1}+\beta_{2} \text { Macro }_{i, t-1}+U_{i}+\varepsilon_{i, t}
$$

Where $N P L_{i, t}$ is the dependent variable of bank $i$ at time $t$; $P L_{i, t-1}$ is the NPL ratio of bank

$i$ at time $t-1$, which captures the persistence in NPLs. Bank $k_{i, t-1}$ is the matrix of bank-specific explanatory variables of bank $i$ at time $t-1 ;$ Macro $_{i, t-1}$ is the matrix of macroeconomic and policy-related variables at time $t-1.10$

8 The unconventional policy tools employed by advanced economies after the crisis led to post-crisis spillovers, causing massive capital flows to emerging economies. This resulted in rapid credit growth, which posed risks to financial stability. Under these circumstances, policymakers had adopted a financial conditions perspective, arguing that financial conditions provide a better guide for monetary policy than more conventional measures such as the monetary conditions index or the real policy rate, which have more commonly been used as measures of monetary policy stance. Accordingly, FCI became popular as a gauge to assess the relative tightness or looseness of financial conditions, which led major central banks as well as international institutions and financial companies to resort to FCI as an important tool for analyzing the economic and monetary policy outlook (Kara et al. 2012, p. 2).

9 Heightened concerns about financial stability triggered a search for an alternative monetary policy framework in small open economies including Turkey. Accordingly, the CBRT adopted financial stability as a supplementary objective to its primary goal of maintaining price stability. This necessitated the use of several tools jointly in the new monetary policy mix, which included the policy rate, an interest rate corridor and required reserves (Başçı and Kara, 2011, p. 9). Also, liquidity policy was used effectively besides reserve options mechanism, which was engineered as a unique macroprudential tool (Küçüksaraç and Özel, 2012, p. 2).

10 The explanatory variables enter the equation with one lag to handle endogeneity. This may arise due to the fact that 
As for the parameters, $\alpha$ is the constant term, while $\beta_{1}$ and $\beta_{2}$ are the corresponding coefficient vectors. The coefficient of persistence is $\gamma$ and it is expected to be positive and less than unity. $U_{i}$ is the unobserved individual (bank-specific) effect and $\varepsilon_{i, t}$ is the idiosyncratic error term, both following i.i.d. processes with mean 0 and variances $\sigma_{u}$ and $\sigma_{\varepsilon}$, respectively. The subscripts $i$ and $t$ range from 1 to $N$ and 1 to $T$, correspondingly, where $N$ is the number of banks and $T$ is the number of periods in the dataset.

The above model is estimated using panel data estimation techniques via fixed effects and random effects models, which take into account the heterogeneity across banks. Alternatively, the equation is also estimated using Generalized Method of Moments (GMM), which eliminates biases that may arise due to the dynamic nature of the model. Accordingly, system GMM is adopted, which is a joint estimation of the above equation in levels and in first differences (Arellano and Bover, 1995; Blundell and Bond, 1998).

\section{Estimation Results}

Tables A3-A4 display the stationarity tests. Accordingly, the panel unit root tests suggest that all the bank-specific explanatory variables are stationary except for asset size, while the time series unit root tests reject the presence of unit root for all the macroeconomic and policy-related determinants. ${ }^{11}$ First differencing the asset size remedies the non-stationarity, which provides that the estimations are no longer exposed to consistency challenges.

Estimations are conducted for the overall sample and by sub-periods, which cover 2002Q42008Q4 and 2009Q1-2015Q4, respectively. ${ }^{12}$ Model selection for random effects and fixed effects is based on Hausman test (Hausman, 1978). ${ }^{13}$ The consistency of the alternative estimation by system GMM estimator relies on the validity of moment conditions, which assumes that the error terms are not serially correlated and the instruments are appropriate. Hence, one should reject the Arellano-Bond first-order serial correlation and do not reject the second-order serial cor-

the NPL ratio and its regressors may be determined simultaneously, which otherwise causes the coefficients to be biased and inconsistent.

11 Stationarity properties of the bank-specific variables are checked by the Levin-Lin-Chu (LLC) test and the less restrictive Im-Pesaran-Shin (IPS) test, which allows for heterogeneous coefficients (Levin et al., 2002; Im et al., 2003). The presence of unit root for macroeconomic and policy-related variables is tested by Augmented DickeyFuller (ADF) statistic (Dickey and Fuller, 1979) and Phillips-Perron (PP) statistic (Phillips and Perron, 1988).

12 The effect of the global crisis was initially captured by the inclusion of a dummy variable for the global crisis in the overall sample, which yielded a statistically significant coefficient. This was further supported by the Chow test, which returned a sufficiently high F-statistic, confirming the presence of a structural break. Obviously, the Chow test only demonstrates that the NPL dynamics have changed during the analyzed period but it fails to tell why this happened. Given that there were no major changes in legislation or no structural changes in the non-financial business sector that might have caused such a break, the mere intuition implies that this must be due to the global crisis, which provides enough evidence for splitting up the sample.

13 Hausman test is used to test the validity of the null hypothesis that the random effects model is preferred due to higher efficiency versus the alternative hypothesis that the fixed effects model is consistent, despite being less efficient. For chi-squared values close to zero, the null hypothesis is rejected, in which case, the fixed effects model is selected. Otherwise, the less restrictive random effects model is accepted. 
relation. Furthermore, Sargan test should indicate that over-identifying restrictions are valid. Accordingly, the p-values of the $\mathrm{AR}(1)$ and $\mathrm{AR}(2)$ tests show no serial correlation, while Sargan test justifies instrument validity in all specifications.

\section{I. Estimations for the Overall Period}

Table A5 reports the results for the overall period. Accordingly, it can be inferred that the selection of the explanatory variables is plausible as the regressors yield mostly significant coefficients, which also have the expected signs. In addition, the fixed effects, random effects and the system GMM estimators produce similar results.

In particular, the NPL ratio is persistent given the positive and sizeable coefficient of the lagged dependent variable. Except for system GMM, capital adequacy is also meaningful with a positive coefficient in other specifications. Makri et al. (2014, p. 203), Rime (2001, p. 791) and Koehn and Santomero (1980, p. 1235) attribute this positive link to the evidence that higher regulatory capital may encourage banks to embark in riskier activities, which result in more toxic credit portfolios.

In addition, lending has a positive and significant coefficient in all specifications. In particular, Keeton and Morris (1987, p. 19), Sinkey and Greenawalt (1991, p. 43), Jiménez and Saurina (2006, p. 71) and Klein (2013, p. 20) prescribe the positive relation between lending and NPLs to the fact that excessive loan growth may expose banks to higher risk, which generates bad loans.

Inefficiency, which is captured by the ratio of other operating expenses to total assets, has a significant positive coefficient. This suggests that inefficiency generates NPLs. In fact, Berger and DeYoung (1997, p. 853), Williams (2004, p. 2429), Espinoza and Prasad (2010, p. 11), Podpiera and Weil (2008, p. 137) and Louzis et al. (2012, p. 1024) discuss that higher inefficiency implies poor loan underwriting, monitoring and cost control, which may increase impaired loans.

Furthermore, except for system GMM, bank size has a positive coefficient in all specifications, which implies that larger banks have higher credit risk. In particular, Stern and Feldman (2004, p. 1) discuss that bank size encourages banks to indulge in excessive risk given higher prospects to be rescued by the government in case of failure. On the other hand, profitability yields positive yet insignificant coefficients in all estimations, which seems intriguing as previous literature reports significant coefficients for profitability. ${ }^{14}$

Macroeconomic and policy-related explanatory variables have also significant coefficients. Particularly, the real GDP growth has a negative coefficient in all estimations. This confirms Jiménez and Saurina (2006, p. 75) and Fofack (2005, p. 11), which observe a reverse link, attributing this to the fact that higher income enhances the debt servicing capacity of borrowers, thus

14 García-Marco and Robles-Fernández (2008, p. 335) state that profitability may drive up NPLs as higher profits are likely to cause risk. On the other hand, Louzis et al. (2012, p. 1016) argue that NPLs may also grow amid lower profitability due to presumably bad management. 
reducing bad loans. Inflation has a positive coefficient in all specifications, which reinforces the income sensitivity of the NPLs. In fact, Klein (2013, p. 4) asserts that inflation may fuel NPLs as it reduces real income.

Meanwhile, exchange rate is positively linked to NPLs in all estimations, which suggests that the depreciation of the Turkish lira may trigger impaired loans. In particular, Kalluci and Kodra (2010, p. 83), Moinescu and Codirlaşu (2012, p. 79) and Fofack (2005, p. 11) discuss that the loss of value in the local currency causes higher NPLs in case of FX lending to unhedged borrowers.

Finally, higher policy rate has a positive coefficient in all specifications. In particular, Berge and Boye (2007, p. 72) discuss that policy rate hikes are likely to be transmitted as greater interest rate on loans. As discussed by Bofondi and Ropele (2011, p. 12) as well as Espinoza and Prasad (2010, p. 3), this adversely affects debt servicing ability via increased interest burden, which therefore induces the likelihood for default.

\subsection{Estimations for the Pre-Crisis and the Post-Crisis Periods}

Table A6 display the estimation results by sub-periods. Accordingly, it can be observed that capital adequacy, lending ${ }^{15}$, asset size and policy rate are statistically significant before the crisis. On the other hand, GDP growth has a significant coefficient only in the post-crisis period. Meanwhile, inefficiency, inflation and exchange rate are statistically significant in both sub-periods, whereas profitability is insignificant both before and after the crisis. As for the persistence of NPLs, the lagged dependent variable is statistically significant in both episodes and the size of the coefficient is even higher after the crisis.

Against this background, it can be concluded that the pre-crisis NPL dynamics are mostly determined by bank-specific variables, while post-crisis dynamics are better described by mac-

roeconomic variables. These findings support the preliminary observations on the evolution of NPLs asserting that the pre-crisis NPL dynamics can be ascribed to the banking sector reform ${ }^{16}$, which had a major impact on banking sector balance sheets, while the post-crisis dynamics are linked with global influences, which weighed heavily on macroeconomic factors and presumably on the domestic financial conditions (Us, 2016b, p. 5).

15 Estimations produce significant coefficient for lending with a negative sign. This confirms Khemraj and Pasha (2009, p. 16) and Vithessonthi (2016, p. 296) that attribute this reverse link to the adoption of stringent lending standards. In fact, the CBRT has placed heavy emphasis on loan growth as a significant element of its policy design in the post-crisis period and assessed that an annual credit growth rate of 15 percent, the reference value, would imply a significant boost in credit impulse and acceleration in economic activity (Kara and Tiryaki, 2013, p. 2). In coordination with the CBRT to slow down credit growth, the Banking Regulation and Supervision Agency of Turkey also adopted measures in October 2013, which were aimed at stabilizing credit growth in compatible with the growth outlook (CBRT, 2014, p. 51).

16 The Turkish economy has experienced a major financial crisis in 2001, which required the banking sector to go through major reforms afterwards. The key elements of these reforms included far-reaching measures for prudential regulation and supervision as well as restructuring and recapitalization of banks. Accordingly, the main pillars of the program include measures for prudential regulation and supervision as well as restructuring of state banks, prompt resolution of insolvent banks and recapitalization of private banks (Ganioğlu and Us, 2014, pp.1-2 and 32-33). 
To further support this finding, post-crisis estimations are re-conducted with the inclusion of the FCI, which captures the stance of financial conditions. It should be noted that a positive value in FCI indicates loose financial conditions, while a negative value implies tight financial conditions (Kara et al., 2015, p. 52). Hence, NPLs are expected to be negatively associated with FCI since relatively tight financial conditions pose an upward pressure on impaired loans. ${ }^{17}$

Against this backdrop, the results show that FCI has a significantly negative coefficient as expected. Also, all the specifications return a meaningful estimate for FCI. Moreover, the inclusion of FCI does not change the significance of other macroeconomic regressors, except for exchange rate, which is no longer significant.

Hence, it can be concluded that FCI, which measures the contribution of both domestic and global factors in financial conditions, can be used to assess the dynamics of bad loans after the crisis. Even though literature often cites bank-specific and macroeconomic factors as potential determinants of NPLs, the analysis draws attention to the role of financial conditions on NPLs and proposes FCI as a plausible variable in understanding impaired loans, which is a measure of financial vulnerability and stability.

\section{Conclusion}

This paper analyzes the determinants of NPLs in the Turkish banking sector. By implementing alternative techniques, the analysis returns similar results. In particular, the findings show that the dynamics of NPLs in the Turkish banking sector have changed after the crisis. The empirical analysis shows that the pre-crisis NPL dynamics can be better described by bank-specific variables. This signifies the effectiveness of the banking sector reform, which caused a major rehabilitation in the banking sector balance sheets. On the other hand, bank-specific variables fail to account for the dynamics of NPLs in the post-crisis episode, while macroeconomic factors have a more accentuated impact on NPLs in this period. This may be attributed to the fact that the post-crisis period is marked by major global developments that also induced strong effects on the domestic macroeconomic and financial conditions. This finding is reinforced by the inclusion of FCI to post-crisis estimations, which returns significant coefficients.

On the other hand, lending is an important determinant, which is significant in both sub-periods. This supports the crucial link between lending and bad loans. However, the impact of lending is negative after the crisis. This implies excessive stringency on lending standards, which cause bad loans. Meanwhile, persistence of the NPL ratio is also a major factor driving the NPL dynamics. This can be confirmed by the significance of the lagged NPL ratio in the overall analysis and also in sub-periods. Yet, the persistence seems to be higher after the crisis given the higher coefficient of the lagged NPL ratio in this period.

17 Klein $(2013$, p. 3) assert that tight financial conditions weaken the borrowers' repayment capacity, while Gumata et al. (2012, p. 5) also associate tightness in financial conditions with increases in NPLs. 
Against this background, it can be concluded that accurate policy for minimizing NPLs is critical for maintaining financial stability. In this regard, macroprudential policies are important given the strong link observed between NPLs and financial conditions after the crisis. This is also verified as NPLs continue to be linked to lending in this period, albeit negatively, which implies that macroprudential policies should not be too stringent as this may also lead to NPLs. In the meantime, financial conditions, which will be shaped by global policy normalization, may affect the course of NPLs in the upcoming period. This poses challenges and prospects regarding financial stability and monetary policy.

For future research, the same analysis could be replicated individually for each loan category. In particular, macroeconomic and bank-specific variables as well as financial conditions may impact each loan type differently. Hence, a distinction may help policymakers to promote financial stability by directly identifying the loan type that is likely to generate NPLs. This evidently requires a thorough understanding of the underlying structural forces driving these loan-based differences, which, however, is beyond the scope of this paper.

\section{Appendix}

\begin{tabular}{|l|l|}
\hline \multicolumn{2}{|l|}{ Table A1. Description of Variables } \\
\hline VARIABLE & DESCRIPTION \\
\hline Dependent variables & \\
\hline NPL/LOANS & Overdue loans to total loans and receivables \\
\hline Independent variables & \\
\hline EQUITY/RWASSETS & Regulatory capital to risk-weighted assets \\
\hline PROFITS/EQUITY & Net profits (loss) to shareholders' equity \\
\hline LOANS/ASSETS & Total loans and receivables to total assets \\
\hline OTHEREXP/ASSETS & Other operating expenses to total assets \\
\hline ASSETS/GDP & Total assets to the GDP \\
\hline GDP & Year-on-year change in the real GDP in logs \\
\hline INFLATION & Year-on-year change in the consumer price index in logs \\
\hline EXCHANGE & Quarter-on-quarter change in USD/TL rate in logs \\
\hline POLICYRATE & Change in the CBRT policy rate \\
\hline FCI & Financial conditions index for Turkey \\
\hline
\end{tabular}


Table A2. Descriptive Statistics

\begin{tabular}{|c|c|c|c|c|c|c|}
\hline & & MEAN & MEDIAN & MIN & MAX & STANDARD DEVIATION \\
\hline \multirow{3}{*}{$\begin{array}{l}\text { NPL/ } \\
\text { LOANS }\end{array}$} & Overall & 0.050 & 0.033 & 0.000 & 0.946 & 0.072 \\
\hline & Pre-Crisis & 0.063 & 0.032 & 0.000 & 0.946 & 0.102 \\
\hline & Post-Crisis & 0.038 & 0.034 & 0.006 & 0.124 & 0.021 \\
\hline \multirow{3}{*}{$\begin{array}{l}\text { EQUITY/ } \\
\text { RWASSETS }\end{array}$} & Overall & 0.201 & 0.159 & 0.036 & 3.161 & 0.162 \\
\hline & Pre-Crisis & 0.241 & 0.169 & 0.036 & 3.161 & 0.226 \\
\hline & Post-Crisis & 0.165 & 0.156 & 0.120 & 0.344 & 0.037 \\
\hline \multirow{3}{*}{$\begin{array}{l}\text { PROFITS/ } \\
\text { EQUITY }\end{array}$} & Overall & 0.074 & 0.068 & -1.786 & 0.618 & 0.106 \\
\hline & Pre-Crisis & 0.081 & 0.078 & -1.786 & 0.618 & 0.141 \\
\hline & Post-Crisis & 0.068 & 0.059 & -0.146 & 0.339 & 0.059 \\
\hline \multirow{3}{*}{$\begin{array}{l}\text { LOANS/ } \\
\text { ASSETS }\end{array}$} & Overall & 0.538 & 0.593 & 0.001 & 0.878 & 0.170 \\
\hline & Pre-Crisis & 0.451 & 0.475 & 0.001 & 0.810 & 0.179 \\
\hline & Post-Crisis & 0.615 & 0.642 & 0.214 & 0.878 & 0.117 \\
\hline \multirow{3}{*}{$\begin{array}{l}\text { OTHEREXP/ } \\
\text { ASSETS }\end{array}$} & Overall & 0.024 & 0.020 & 0.004 & 0.274 & 0.020 \\
\hline & Pre-Crisis & 0.029 & 0.023 & 0.004 & 0.274 & 0.025 \\
\hline & Post-Crisis & 0.019 & 0.018 & 0.004 & 0.065 & 0.010 \\
\hline \multirow{3}{*}{$\begin{array}{l}\text { ASSETS/ } \\
\text { GDP }\end{array}$} & Overall & 0.133 & 0.055 & 0.000 & 0.611 & 0.157 \\
\hline & Pre-Crisis & 0.099 & 0.039 & 0.000 & 0.448 & 0.119 \\
\hline & Post-Crisis & 0.164 & 0.074 & 0.002 & 0.611 & 0.179 \\
\hline \multirow{3}{*}{ GDP } & Overall & 0.047 & 0.051 & -0.159 & 0.119 & 0.049 \\
\hline & Pre-Crisis & 0.059 & 0.068 & -0.072 & 0.113 & 0.037 \\
\hline & Post-Crisis & 0.036 & 0.040 & -0.159 & 0.119 & 0.055 \\
\hline \multirow{3}{*}{ INFLATION } & Overall & 0.093 & 0.083 & 0.043 & 0.275 & 0.045 \\
\hline & Pre-Crisis & 0.114 & 0.091 & 0.069 & 0.275 & 0.058 \\
\hline & Post-Crisis & 0.075 & 0.076 & 0.043 & 0.100 & 0.014 \\
\hline \multirow{3}{*}{ EXCHANGE } & Overall & 0.011 & 0.010 & -0.086 & 0.241 & 0.060 \\
\hline & Pre-Crisis & -0.003 & -0.018 & -0.086 & 0.241 & 0.070 \\
\hline & Post-Crisis & 0.023 & 0.021 & -0.052 & 0.102 & 0.045 \\
\hline \multirow{3}{*}{$\begin{array}{l}\text { POLICY- } \\
\text { RATE }\end{array}$} & Overall & -0.007 & -0.003 & -0.083 & 0.034 & 0.019 \\
\hline & Pre-Crisis & -0.012 & -0.005 & -0.083 & 0.034 & 0.023 \\
\hline & Post-Crisis & -0.003 & -0.001 & -0.037 & 0.027 & 0.013 \\
\hline FCI & Post-Crisis & 0.017 & 0.016 & -0.193 & 0.233 & 0.100 \\
\hline
\end{tabular}


Table A3. Panel Unit Root Tests

\begin{tabular}{|l|l|l|l|l|l|}
\hline & IPS & LLC & $\begin{array}{l}\text { Critical Value } \\
(1 \%)\end{array}$ & $\begin{array}{l}\text { Critical Value } \\
(5 \%)\end{array}$ & $\begin{array}{l}\text { Critical Value } \\
(10 \%)\end{array}$ \\
\hline $\begin{array}{l}\text { NPL/ } \\
\text { LOANS }\end{array}$ & -3.377 & -23.441 & -1.930 & -1.810 & -1.750 \\
\hline $\begin{array}{l}\text { EQUITY/ } \\
\text { RWASSETS }\end{array}$ & -3.046 & -12.937 & -1.930 & -1.810 & -1.750 \\
\hline $\begin{array}{l}\text { PROFITS/ } \\
\text { EQUITY }\end{array}$ & -6.148 & -19.337 & -1.930 & -1.810 & -1.750 \\
\hline $\begin{array}{l}\text { LOANS/ } \\
\text { ASSETS }\end{array}$ & -2.405 & -8.768 & -1.930 & -1.810 & -1.750 \\
\hline $\begin{array}{l}\text { OTHEREXP/ } \\
\text { ASSETS }\end{array}$ & -7.003 & -23.801 & -1.930 & -1.810 & -1.750 \\
\hline $\begin{array}{l}\text { ASSETS/ } \\
\text { GDP }\end{array}$ & -0.717 & -1.802 & -1.930 & -1.810 & -1.750 \\
\hline Notes: Panel unit root tests are based on the assumption of anel mean with no time trend. \\
\hline
\end{tabular}

Table A4. Time Series Unit Root Tests

\begin{tabular}{|l|l|l|l|l|l|}
\hline & $\begin{array}{l}\text { ADF Test Sta- } \\
\text { tistic }\end{array}$ & PP Test Statistic & $\begin{array}{l}\text { Critical Value } \\
(1 \%)\end{array}$ & $\begin{array}{l}\text { Critical Value } \\
(5 \%)\end{array}$ & $\begin{array}{l}\text { Critical Value } \\
(10 \%)\end{array}$ \\
\hline GDP & -2.692 & -2.982 & -3.592 & -2.931 & -2.604 \\
\hline INFLATION & -6.016 & -8.952 & -3.574 & -2.924 & -2.600 \\
\hline EXCHANGE & -6.429 & -6.429 & -3.563 & -2.919 & -2.597 \\
\hline POLICYRATE & -3.351 & -3.250 & -3.565 & -2.920 & -2.598 \\
\hline FCI & -2.783 & -3.711 & -2.981 & -2.630 \\
\hline Notes: Unit root tests are based on the assumption of a constant with no time trend. \\
\hline
\end{tabular}

Table A5. Estimation Results for the Overall Period

\begin{tabular}{|l|l|l|l|}
\hline & FIXED & $\begin{array}{l}\text { RANDOM } \\
\text { EFFECTS }\end{array}$ & $\begin{array}{l}\text { SYSTEM } \\
\text { GMM }\end{array}$ \\
\hline EFFECTS & $0.808^{* * *}$ & $0.831^{* * *}$ & $0.814^{* *}$ \\
LOANS(-1) & $(0.011)$ & $0.009)$ & $(0.014)$ \\
\hline EQUITY/ & $0.037^{* * *}$ & $0.024^{* * *}$ & 0.012 \\
RWASSETS(-1) & $(0.005)$ & $(0.005)$ & $(0.008)$ \\
\hline PROFITS/ & 0.001 & 0.009 & 0.005 \\
EQUITY(-1) & $(0.006)$ & $(0.005)$ & $(0.007)$ \\
\hline LOANS/ & $0.020^{* * *}$ & $0.016^{* * *}$ & $0.010^{*}$ \\
ASSETS(-1) & $(0.006)$ & $(0.004)$ & $(0.006)$ \\
\hline OTHEREXP/ & $0.116^{* * *}$ & $0.133^{* * *}$ & $0.091^{* * *}$ \\
ASSETS(-1) & $(0.036)$ & $(0.032)$ & $(0.034)$ \\
\hline$\triangle$ ASSETS/ & $0.061^{*}$ & $0.075^{* *}$ & 0.043 \\
GDP & $(0.034)$ & $(0.034)$ & $(0.031)$ \\
\hline
\end{tabular}




\begin{tabular}{|c|c|c|c|}
\hline GDP(-1) & $\begin{array}{l}-0.040^{* * *} \\
(0.013) \\
\end{array}$ & $\begin{array}{l}-0.040^{* * *} \\
(0.012) \\
\end{array}$ & $\begin{array}{l}-0.045^{* * *} \\
(0.010) \\
\end{array}$ \\
\hline INFLATION(-1) & $\begin{array}{l}0.067^{* * *} \\
(0.016) \\
\end{array}$ & $\begin{array}{l}0.059^{* * *} \\
(0.016)\end{array}$ & $\begin{array}{l}0.077^{\star * *} \\
(0.020)\end{array}$ \\
\hline EXCHANGE(-1) & $\begin{array}{l}0.021^{\star *} \\
(0.010) \\
\end{array}$ & $\begin{array}{l}0.022^{* \star} \\
(0.010)\end{array}$ & $\begin{array}{l}0.023^{\star * *} \\
(0.008)\end{array}$ \\
\hline POLICYRATE & $\begin{array}{l}0.144^{* * *} \\
(0.040) \\
\end{array}$ & $\begin{array}{l}0.146^{* * *} \\
(0.040)\end{array}$ & $\begin{array}{l}0.128^{\star * *} \\
(0.039) \\
\end{array}$ \\
\hline CONSTANT & $\begin{array}{l}-0.018^{\star * *} \\
(0.004) \\
\end{array}$ & $\begin{array}{l}-0.015^{\star * *} \\
(0.003) \\
\end{array}$ & $\begin{array}{l}-0.008^{\star *} \\
(0.004) \\
\end{array}$ \\
\hline F-statistics & $\begin{array}{l}1188.08 \\
(0.000)\end{array}$ & - & - \\
\hline Wald chi-squared & - & $\begin{array}{l}13623.19 \\
(0.000) \\
\end{array}$ & $\begin{array}{l}10815.03 \\
(0.000) \\
\end{array}$ \\
\hline $\operatorname{AR}(1)$ & - & - & 0.032 \\
\hline $\operatorname{AR}(2)$ & - & - & 0.773 \\
\hline Sargan & - & - & 0.740 \\
\hline Hausman Test & $\begin{array}{l}40.67 \\
\text { (chi-squared=0.000) }\end{array}$ & & - \\
\hline Number of Observations & 1092 & & \\
\hline
\end{tabular}

Table A6. Estimation Results by Sub-Periods

\begin{tabular}{|l|l|l|l|l|l|l|}
\hline & \multicolumn{3}{|l|}{ Pre-Crisis Period } & \multicolumn{2}{l|}{ Post-Crisis Period } \\
& $\begin{array}{l}\text { FIXED } \\
\text { EFFECTS }\end{array}$ & $\begin{array}{l}\text { RANDOM } \\
\text { EFFECTS }\end{array}$ & $\begin{array}{l}\text { SYSTEM } \\
\text { GMM }\end{array}$ & $\begin{array}{l}\text { FIXED } \\
\text { EFFECTS }\end{array}$ & $\begin{array}{l}\text { RANDOM } \\
\text { EFFECTS }\end{array}$ & $\begin{array}{l}\text { SYSTEM } \\
\text { GMM }\end{array}$ \\
\hline NPL/ & $0.792^{* * *}$ & $0.825^{* *}$ & $0.726^{* * *}$ & $0.794^{* * *}$ & $0.923^{* * *}$ & $0.827^{* * *}$ \\
LOANS(-1) & $(0.018)$ & $(0.014)$ & $(0.027)$ & $0.023)$ & $(0.013)$ & $(0.020)$ \\
\hline EQUITY/ & $0.047^{* * *}$ & $0.031^{* * *}$ & 0.014 & -0.002 & -0.011 & -0.003 \\
RWASSETS(-1) & $(0.008)$ & $(0.007)$ & $(0.013)$ & $(0.011)$ & $(0.009)$ & $(0.010)$ \\
\hline PROFITS/ & -0.005 & 0.005 & -0.006 & 0.004 & -0.001 & 0.004 \\
EQUITY(-1) & $(0.009)$ & $(0.008)$ & $(0.013)$ & $(0.006)$ & $(0.005)$ & $(0.006)$ \\
\hline LOANS/ & $0.061^{* * *}$ & $0.029^{* * *}$ & $0.028^{*}$ & $-0.010^{* *}$ & 0.001 & $-0.011^{* *}$ \\
ASSETS(-1) & $(0.015)$ & $(0.009)$ & $(0.017)$ & $(0.004)$ & $(0.003)$ & $(0.004)$ \\
\hline OTHEREXP/ & $0.148^{* *}$ & $0.109^{* *}$ & 0.072 & 0.026 & $0.045^{*}$ & 0.006 \\
ASSETS(-1) & $(0.063)$ & $(0.053)$ & $(0.062)$ & $(0.031)$ & $(0.028)$ & $(0.030)$ \\
\hline AASSETS/ & $0.107^{*}$ & $0.109^{*}$ & 0.080 & 0.015 & 0.013 & 0.025 \\
GDP & $(0.065)$ & $(0.065)$ & $(0.059)$ & $(0.018)$ & $(0.018)$ & $(0.016)$ \\
\hline GDP(-1) & 0.029 & -0.018 & -0.002 & $-0.028^{* * *}$ & $-0.021^{* * *}$ & $-0.027^{* * *}$ \\
\hline INFLATION(-1) & $(0.051)$ & $(0.048)$ & $(0.045)$ & $(0.005)$ & $(0.005)$ & $(0.005)$ \\
\hline EXCHANGE(-1) & $0.117^{* * *}$ & $0.088^{* * *}$ & $0.179^{* * *}$ & -0.013 & -0.006 & $0.026^{*}$ \\
& $(0.028)$ & $(0.026)$ & $(0.037)$ & $(0.017)$ & $(0.017)$ & $(0.014)$ \\
\hline & 0.029 & 0.021 & $0.049^{*}$ & $0.021^{* * *}$ & $0.0023^{* * *}$ & $0.019^{* * *}$ \\
& $(0.029)$ & $(0.029)$ & $(0.027)$ & $(0.004)$ & $(0.004)$ & $(0.004)$ \\
\hline
\end{tabular}




\begin{tabular}{|c|c|c|c|c|c|c|}
\hline POLICYRATE & $\begin{array}{l}0.132 \\
(0.082)\end{array}$ & \begin{tabular}{|l|}
$0.195^{\star * *}$ \\
$(0.075)$ \\
\end{tabular} & $\begin{array}{l}0.140 \\
(0.086)\end{array}$ & $\begin{array}{l}-0.011 \\
(0.025) \\
\end{array}$ & $\begin{array}{l}-0.003 \\
(0.026)\end{array}$ & $\begin{array}{l}-0.017 \\
(0.024)\end{array}$ \\
\hline CONSTANT & $\begin{array}{l}-0.048^{* * *} \\
(0.011)\end{array}$ & $\begin{array}{l}-0.024^{* * *} \\
(0.007)\end{array}$ & $\begin{array}{l}-0.023^{* *} \\
(0.011)\end{array}$ & $\begin{array}{l}-0.014^{* * *} \\
(0.004)\end{array}$ & $\begin{array}{l}0.003 \\
(0.003)\end{array}$ & $\begin{array}{l}0.011^{* *} \\
(0.004)\end{array}$ \\
\hline F-statistics & $\begin{array}{l}435.23 \\
(0.000)\end{array}$ & - & - & $\begin{array}{l}258.62 \\
(0.000)\end{array}$ & & \\
\hline Wald chi-squared & - & $\begin{array}{l}6212.27 \\
(0.000)\end{array}$ & $\begin{array}{l}2377.14 \\
(0.000)\end{array}$ & & $\begin{array}{l}6798.69 \\
(0.000)\end{array}$ & $\begin{array}{l}4284.36 \\
(0.000)\end{array}$ \\
\hline Sargan & - & - & 0.675 & & & 0.117 \\
\hline $\operatorname{AR}(1)$ & - & - & 0.050 & & & 0.004 \\
\hline $\mathrm{AR}(2)$ & - & - & 0.772 & & & 0.471 \\
\hline Hausman Test & \multicolumn{2}{|c|}{$\begin{array}{l}35.00 \\
\text { (chi-squared }=0.000 \text { ) }\end{array}$} & - & \multicolumn{2}{|c|}{$\begin{array}{l}52.85 \\
\text { (chi-squared=0.000) }\end{array}$} & - \\
\hline $\begin{array}{l}\text { Number of Observa- } \\
\text { tions }\end{array}$ & \multicolumn{3}{|l|}{504} & \multicolumn{3}{|l|}{588} \\
\hline
\end{tabular}

Table A7. Estimation Results for the Post-Crisis Period

\begin{tabular}{|l|l|l|l|}
\hline & FIXED & RANDOM & SYSTEM \\
& EFFECTS & EFFETS & GMM \\
\hline NPL/ & $0.789^{* * *}$ & $0.915^{* * *}$ & $0.814^{* * *}$ \\
LOANS(-1) & $(0.024)$ & $(0.013)$ & $(0.020)$ \\
\hline EQUITY/ & -0.008 & -0.013 & -0.009 \\
RWASSETS(-1) & $(0.011)$ & $(0.009)$ & $(0.010)$ \\
\hline PROFITS/ & 0.001 & -0.002 & -0.001 \\
EQUITY(-1) & $(0.006)$ & $(0.005)$ & $(0.006)$ \\
\hline LOANS/ & $-0.009^{* *}$ & 0.002 & $-0.007^{*}$ \\
ASSETS(-1) & $(0.004)$ & $(0.003)$ & $(0.004)$ \\
\hline OTHEREXP/ & 0.032 & 0.044 & 0.038 \\
ASSETS(-1) & $(0.030)$ & $(0.027)$ & $(0.029)$ \\
\hline AASSETS/ & 0.009 & 0.011 & 0.004 \\
GDP & $(0.019)$ & $(0.019)$ & $(0.019)$ \\
\hline GDP(-1) & $-0.025^{* * *}$ & $-0.015^{* * *}$ & $-0.024^{* * *}$ \\
\hline INFLATION(-1) & $(0.006)$ & $(0.006)$ & $(0.005)$ \\
\hline EXCHANGE(-1) & $-0.035^{* *}$ & $-0.035^{* *}$ & $-0.041^{* * *}$ \\
\hline POLICYRATE & $(0.017)$ & $(0.018)$ & $(0.016)$ \\
\hline FCI(-1) & 0.006 & 0.004 & 0.005 \\
& $(0.006)$ & $(0.006)$ & $(0.006)$ \\
\hline CONSTANT & 0.001 & -0.001 & -0.003 \\
& $(0.027)$ & $(0.028)$ & $(0.025)$ \\
\hline & $-0.006^{* *}$ & $-0.011^{* * *}$ & $-0.008^{* * *}$ \\
& $(0.003)$ & $(0.003)$ & $(0.003)$ \\
\hline & $0.017^{* * *}$ & $0.006^{*}$ & $0.015^{* * *}$ \\
$(0.004)$ & $(0.003)$ & $(0.040)$ \\
\hline
\end{tabular}




\begin{tabular}{|l|l|l|l|}
\hline F-statistics & $\begin{array}{l}220.39 \\
(0.000)\end{array}$ & - & - \\
\hline Wald chi-squared & - & $\begin{array}{l}6721.16 \\
(0.000)\end{array}$ & $\begin{array}{l}3727.71 \\
(0.000)\end{array}$ \\
\hline Sargan & - & - & 0.625 \\
\hline AR(1) & - & - & 0.004 \\
\hline AR(2) & - & - & 0.476 \\
\hline Hausman Test & $\begin{array}{l}\text { p58.02 } \\
(\text { chi-squared }=0.000)\end{array}$ & - \\
\hline Number of Observations & 567 & \\
\hline $\begin{array}{l}\text { Notes: } \Delta \text { denotes the difference operator. }{ }^{*},{ }^{* *},{ }^{* * *} \text { denote statistical significance at } 1,5 \text { and } 10 \text { percent, respectively. } \\
\text { Standard errors, probability for Wald chi-squared and F-statistics are reported in parenthesis. }\end{array}$ \\
\hline
\end{tabular}

\section{REFERENCES}

AFŞAR, M., 2011, Küresel Kriz ve Türk Bankacılık Sektörüne Yansımaları (in Turkish), Eskişehir Osmangazi Üniversitesi İ̈BF Dergisi, 6(2): 143-171.

ARELLANO, M. and O. BOVER, 1995, Another look at the instrumental variable estimation of error-components models, Journal of Econometrics, 68(1): 29-51.

BAŞÇI, E. and H. KARA, 2011, Finansal İstikrar ve Para Politikası (in Turkish), İktisat İşletme ve Finans, 26(302): 9-25.

BERGE, T.O. and K.G. Boye, 2007, An analysis of bank's problem loans, Norges Bank Economic Bulletin, 78(2): 65-76.

BERGER, A.N. and R. DE YOUNG, 1997, Problem loans and cost efficiency in commercial banks, Journal of Banking \& Finance, 21(6): 849-870.

BLUNDELL, R. and S. BOND, 1998, Initial conditions and moment restrictions in dynamic panel data models, Journal of Econometrics, 87(1): 115-143.

BOFONDI, M. and T. ROPELE, 2011, Macroeconomic Determinants of Bad Loans: Evidence from Italian Banks, Bank of Italy Occasional Paper No. 89.

CBRT, 2010, Financial Stability Report, December, available at http://www.tcmb.gov.tr/wps/wcm/connect/93f51ef9-f063-4496-b3ad-e7e83121eb87/fulltext11.pdf?MOD=AJPERES\&CACHEID=93f51ef9-f063-4496-b3ad-e7e83121eb87., 2014, Financial Stability Report, November, availableathttp://www.tcmb.gov.tr/wps/wcm/connect/02ac065c-64df-499c-a5cb-c7aca359c21d/fulltext19.pdf?MOD=AJPERES\&CACHEID=ROOTWORKSPACE-02ac065c-64df-499c-a5cb-c7aca359c21d-kNaQgOz.

DICKEY, D.A. and W.A. FULLER, 1979, Distribution of the estimators for autoregressive time series with a unit root, Journal of the American Statistical Association, 74(366): 427-431.

ESPINOZA, R. and A. PRASAD, 2010, Nonperforming Loans in the GCC Banking Systems and their Macroeconomic Effects, IMF Working Paper No. 10/224.

ESTRELLA, A. and G.A. HARDOUVELIS, 1991, The Term Structure as a Predictor of Real Economic Activity, The Journal of Finance, 46(2): 555-576.

ESTRELLA, A. and F. MISHKIN, 1998, Predicting U.S. Recessions: Financial Variables as Leading Indicators, Review of Economics and Statistics, 80(1): 45-61.

FOFACK, H., 2005, Non-Performing Loans in Sub-Saharan Africa: Causal Analysis and Macroeconomic Implications, World Bank Policy Research Working Paper No. 3769. 
GANiOĞLU, A. and V. US, 2014, The Structure of the Turkish Banking Sector Before and After the Global Crisis, CBRT Working Paper No. 14/29.

GARCÍA-MARCO, T. and M.D. ROBLES-FERNÁNDEZ, 2008, Risk-taking behavior and ownership in the banking industry: The Spanish evidence, Journal of Economics and Business, 60(4): 332-354.

GILCHRIST, S., V. YANKOV and E. ZAKRAJSEK, 2009, Credit Market Shocks and Economic Fluctuations: Evidence from Corporate Bond and Stock Markets, Journal of Monetary Economics, 56(4): 471-493.

GUMATA, N., N. KLEIN and E. NDOU, 2012, A Financial Conditions Index for South Africa, IMF Working Paper No. 12/196.

HARVEY, C., 1988, The Real Term Structure and Consumption Growth, Journal of Financial Economics, 22(2): 305-333.

HATZIUS, J., P. HOOPER, F.S. MISHKIN, K.L. SCHOENHOLTZ and M.W. WATSON, 2010, Financial Conditions Indexes: A Fresh Look after the Financial Crisis, NBER Working Papers No. 16150.

HAUSMAN, J.A., 1978, Specification Tests in Econometrics, Econometrica, 46(6): 1251-1271.

IM, K.S., M.H. PESARAN and Y. SHIN, 2003, Testing for unit roots in heterogeneous panels, Journal of Econometrics, 115(1): 53-74.

JIMÉNEZ, G. and J. SAURINA, 2006, Credit cycles, credit risk, and prudential regulation, International Journal of Central Banking, 2(2): 65-98.

KALLUCI, I. and O. KODRA, 2010, Macroeconomic Determinants of Credit Risk: The case of Albania, in A. Fullani (ed.), Economic Policies in SEE: Design, Performance and Challenges, Bank of Albania.

KARA, H., P. ÖZLÜ and D. ÜNALMIŞ, 2012, Financial Conditions Indices for the Turkish Economy, CBT Research Notes in Economics No. 12/31., 2015, Türkiye için Finansal Koşullar Endeksi (in Turkish), Central Bank Review, 15(3): 41-73.

KARA, H. and S.T. TİRYAKİ, 2013, Kredi İvmesi ve İktisadi Konjonktür (in Turkish), CBT Research Notes in Economics No. 13/10.

KEETON, W.R. and C.S. MORRIS, 1987, Why Do Banks' Loan Losses Differ?, Federal Reserve Bank of Kansas City, Economic Review, 72(5): 3-21.

KHEMRAJ, T. and S. PASHA, 2009, The determinants of non-performing loans: An econometric case study of Guyana, MPRA Paper No. 53128.

KLEIN, N., 2013, Non-Performing Loans in CESEE: Determinants and Impact on Macroeconomic Performance, IMF Working Paper No. 13/72.

KOEHN, M. and A. SANTOMERO, 1980, Regulation of bank capital and portfolio risk, Journal of Finance, 35(5): 1235-1244.

KÜÇÜKSARAÇ, D. and Ö. ÖZEL, 2012, Rezerv Opsiyonu Mekanizması ve Optimal Rezerv Opsiyonu Katsayılarının Hesaplanması (in Turkish), CBRT Working Paper No. 12/3.

LAURENT, R., 1989, Testing the Spread, Economic Perspectives, 13(4): 22-34.

LEVIN, A., C.F. LIN and C.S.J. CHU, 2002, Unit root tests in panel data: Asymptotic and finite-sample properties, Journal of Econometrics, 108(1): 1-24.

LOUZIS, D.P., A.T. VOUILDIS and V.L. METAXAS, 2012, Macroeconomic and bank-specific determinants of non-performing loans in Greece: A comparative study of mortgage, business and consumer loan portfolios, Journal of Banking \& Finance, 36(4): 1012-1027.

MAKRI, V., A. TSAGKANOS and A. BELLAS, 2014, Determinants of Non-Performing Loans: The Case of Eurozone, Panoeconomicus, 61(2): 193-206. 
MOINESCU, B. and A. CODIRLAŞU, 2012, Assessing the Sectoral Dynamics of Non-performing Loans: Signs from Financial and Real Economy, Theoretical and Applied Economics, XIX(2): 69-80.

PHILLIPS, P.C.B. and P. PERRON, 1988, Testing for a Unit Root in Time Series Regression, Biometrika, 75(2): 335-346.

PODPIERA, J. and L. WEILL, 2008, Bad Luck or Bad Management? Emerging Banking Market Experience, Journal of Financial Stability, 4(2): 135-148.

REINHART, C. and K. ROGOFF, 2011, From Financial Crash to Debt Crisis, American Economic Review, 101(5): 1676-1706.

RIME, B., 2001, Capital requirements and bank behaviour: empirical evidence for Switzerland, Journal of Banking \& Finance, 25(5): 789-805.

RINALDI, L. and A. SANCHIS-ARELLANO, 2006, Household Debt Sustainability: What Explains Household Non-Performing Loans? An Empirical Analysis, ECB Working Paper No. 570.

SALAS, V. and J. SAURINA, 2002, Credit Risk in Two Institutional Regimes: Spanish Commercial and Savings Banks, Journal of Financial Services Research, 22(3): 203-224.

SELÇUK, B., 2010, Küresel Krizin Türk Finans Sektörü Üzerindeki Etkileri (in Turkish), Ekonomi Bilimleri Dergisi, 2(2): 21-27.

SINKEY, J.F. and M.B. GREENAWALT, 1991, Loan-Loss Experience and Risk-Taking Behavior at Large Commercial Banks, Journal of Financial Services Research, 5(1): 43-59.

STERN, G.H. and R.J. FELDMAN, 2004, Too Big To Fail: The Hazards of Bank Bailouts, Brookings Institution Press, Washington, DC, USA.

US, V., 2016a, Determinants of Non-Performing Loans in the Turkish Banking Sector: What Has Changed after the Global Crisis, CBT Research Notes in Economics No. 16/27., 2016b, A Dynamic Approach to Analysing the Effect of the Global Crisis on Non-Performing Loans: Evidence from the Turkish Banking Sector, Applied Economics Letters, 24(3): 186-192.

VITHESSONTHI, C., 2016, Deflation, bank credit growth, and non-performing loans: Evidence from Japan, International Review of Financial Analysis, 45(2016): 295-305.

WILLIAMS, J., 2004, Determining Management Behaviour in European Banking, Journal of Banking \& Finance, 28(10): 2427-2460. 